\title{
Serological studies on the role of Chlamydia in the aetiology of non-specific urethritis
}

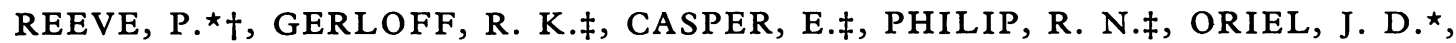 \\ AND POWIS, P. A.* \\ From the Department of Venereal Diseases, St. Thomas's Hospital, London , the Department of Bacteriology, \\ University College Hospital Medical School, London†, and the Rocky Mountain Laboratory, Hamilton, \\ Montana, U.S.A.‡
}

Since the development of an efficient cell-culture technique for the isolation of Chlamydia (Gordon and Quan, 1965; Gordon, Harper, Quan, Treharne, Dwyer, and Garland, 1969), studies of the role of these agents in non-specific genital infection have progressed rapidly. Recent investigations (Dunlop, Vaughan-Jackson, Darougar, and Jones, 1972; Richmond, Hilton, and Clarke, 1972; Oriel, Reeve, Powis, Miller, and Nicol, 1972) have shown that Chlamydia can be recovered from upwards of 40 per cent. of men with non-specific urethritis (NSU), but not from sexually active men with no history or present evidence of NSU. Further refinements of clinical methods, or of the cell-culture system itself, may raise the isolation rate of Chlamydia in men with NSU, but at present there is a large number of men with NSU in whom no direct evidence of chlamydial infection can be found.

The use of serological techniques might provide evidence of chlamydial infection in men with NSU from whom Chlamydia have not been isolated. Previous workers have shown that the use of the Chlamydia group-reactive complement fixation (CF) test in NSU is unrewarding (Barwell, Dunlop, and Race, 1967). More recently, however, two other serological tests have been shown to be of more value in demonstrating chlamydial antibodies. The radioimmune precipitation (RIP) test (Gerloff and Watson, 1967) is, like the CF test, group-reactive, but is approximately twenty times more sensitive (Philip, Hill, Greaves, Gordon, Quan, Gerloff, and Thomas, 1971). In addition, Wang (1971) has devised a micro-immunofluorescent (IF) procedure which is type-specific and has the further advantage that individual immunoglobulins such as $\operatorname{IgM}$ can be measured. Similar immunofluorescent techniques have been used by Hanna, Jawetz, Nabli, Hoshiwara, Ostler, and Dawson, (1972) and by Collier, Sowa, and Sowa (1972) to assay antibodies in the sera of patients with trachoma, with good correlation between antibody levels and clinical disease.

Received for publication August 22, 1973
Dwyer, Treharne, Jones, and Herring (1972) tested a small number of sera from patients with ocular or genital chlamydial infections by the micro-immunofluorescence test and also concluded this to be more sensitive than the group reactive $\mathrm{CF}$ test and equally as sensitive as the RIP test. They claimed that the micro-IF test can give positive indication of chlamydial infection when microbiological evidence is lacking.

In the present investigation we have used the RIP and IF tests to measure antibodies in sera from:

(1) Men with NSU who yielded chlamydial isolates, (2) Men with NSU who did not yield chlamydial isolates,

(3) A 'control' group of men with no history or present evidence of NSU.

Our intentions were, firstly, to ascertain whether patients with Chlamydia-positive NSU exhibited a serological response which could be detected by the RIP and IF tests and, secondly, to see whether these tests could be used to indicate the presence of chlamydial infection in patients with NSU who were negative on cell-culture.

\section{Material and methods}

\section{PATIENTS}

The patients were all seen in the Department of Venereal Diseases, St. Thomas's Hospital. Urethral specimens for Chlamydia culture were collected from 103 men with first attacks of NSU; the criteria for the diagnosis of NSU and the technique of specimen collection have been described elsewhere (Oriel and others, 1972). Sera were taken from the patients on their first attendance.

In addition, 37 'control' men were examined. These were men attending the Department who gave no past history of urethritis; they were examined not less than 4 hours after passing urine, and if there was no manifest urethral discharge and both specimens of urine in a 2-glass test were clear, it was concluded that there was no present evidence of urethritis, and they were included in this group. Sera were taken from these patients when they first attended. Serum samples were stored at $-20^{\circ} \mathrm{C}$. until tests were performed. 
SEROLOGICAL TESTS

Chlamydial antibodies were assayed at the Rocky Mountain Laboratory, Hamilton, Montana, U.S.A.

RIP TFST

This was performed by the method of Gerloff and Watson (1967), using a meningopneumonitis antigen (mpu-Cal 10) radioactively labelled with ${ }^{32} \mathrm{P}$. Sera were tested in 2 -fold dilutions from $1: 32$, and positive and negative control sera were included in each batch tested.

IF TEST

The method of Wang (1971) was used. Antigens used (Table I) were selected as representative of established chlamydial sub-groups. Sera were tested in 2-fold dilutions from 1:8 against each antigen, using fluorescein-labelled goat anti-human IgG and rabbit anti-human IgM.

\section{Results}

\section{IgG levels}

Sera from patients with Chlamydia-positive NSU and Chlamydia-negative NSU and from 'controls' were examined by the RIP and IF tests (Table II). If either test was to prove of value, a significant proportion of the sera from men with Chlamydia-positive NSU should show the presence of chlamydial antibodies. Of 74 sera from men in this category, seventy (94 per cent.) were positive with the RIP test (titres of $1: 32$ or greater against the meningopneumonitis antigen) and 64 ( 86 per cent.) were positive with the IF test (titres of $1: 8$ or greater against any of the antigens). The geometric mean titres (GMT) of the sera in this group were 156 in the RIP test and 26 in the IF test.

Sera from 29 men with Chlamydia-negative NSU were also examined. Of these 29 sera, sixteen ( 55 per cent.) were positive with the RIP test and seven (24 per cent.) with the IF test (Table II). The GMT was 70 and 16 respectively. In these men, serological evidence of chlamydial infection was distinctly less than in the Chlamydia-positive group.

Finally, 37 'control' sera, from men with no past history of urethritis and no present evidence of NSU as defined above, were tested. Of these 37 sera, twenty (54 per cent.) were positive with the RIP test and fourteen (38 per cent.) with the IF test; the GMT was 55 and 10 respectively. In this 'control' group there appeared to be the same prevalence of chlamydial antibodies as in the men with NSU from whom Chlamydia had not been isolated.

\section{IgM levels}

The presence of IgM immunoglobulins indicates a recent infection. Chlamydial IgM antibodies were found in 21 of 74 men ( 28 per cent.) with Chlamydiapositive NSU, in one of 29 men (3 per cent.) with

TABLE I Serological classification of sera reacting in the microimmunofluorescence test

\begin{tabular}{|c|c|c|c|c|c|c|c|c|c|c|}
\hline \multicolumn{8}{|l|}{ Trachoma serotypes } & \multicolumn{3}{|c|}{$\begin{array}{l}\text { Lymphogranuloma } \\
\text { venereum serotypes }\end{array}$} \\
\hline Serotype: ${ }^{a}$ & A & B & C & $\mathrm{D}$ & $\mathbf{E}$ & $\mathrm{F}$ & I & I & II & III \\
\hline Strain: & G17 & TW5 & TW3 & UW3 & UW5 & UW6 & DC049 & 440 & DC009 & 404 \\
\hline $\begin{array}{ll}\text { Clinical categoryb } & \text { A } \\
& \text { C }\end{array}$ & $\begin{array}{r}9 \\
11 \\
13\end{array}$ & $\begin{array}{r}9 \\
13 \\
4\end{array}$ & $\begin{array}{l}4 \\
6 \\
2\end{array}$ & $\begin{array}{l}16 \\
17 \\
22\end{array}$ & $\begin{array}{r}11 \\
11 \\
9\end{array}$ & $\begin{array}{l}5 \\
9 \\
0\end{array}$ & $\begin{array}{l}7 \\
4 \\
0\end{array}$ & $\begin{array}{r}10 \\
6 \\
9\end{array}$ & $\begin{array}{l}15 \\
15 \\
20\end{array}$ & $\begin{array}{r}13 \\
9 \\
11\end{array}$ \\
\hline All groups & 11 & 9 & 4 & 19 & 11 & 5 & 4 & 8 & 17 & 11 \\
\hline
\end{tabular}

aserotypes designated according to the system of Wang and Grayston (1971)

${ }^{b}$ Clinical categories as given in Table II. Figures represent percentages of sera with maximum titres against the respective serotypes

TABLE II Chlamydial antibodies in non-specific urethritis



aRIP = Radioisotope precipitation test. IF $=$ Microimmunofluorescence test

${ }^{b}$ Figures represent numbers of patients having serum titres of $1: 32$ or more (RIP test) and $1: 8$ or more (IF test)

cGeometric mean titre (reciprocal) 
Chlamydia-negative NSU, and in none of the 37 'controls'.

\section{Discussion}

Our results indicate that both the RIP and the IF tests are capable of detecting chlamydial antibodies in sera from patients with NSU from whom Chlamydia have been isolated. Sera were collected from these patients on their first attendance, and it is surprising that such a high proportion showed raised IgG levels; presumably these antibodies increase rapidly after genital chlamydial infection. It is of interest that IgM chlamydial antibodies, which indicate a recent infection, were much more often found in sera from men with Chlamydia-positive NSU than from men with Chlamydia-negative NSU or the 'controls'.

Nearly one-half of the 'control' sera were positive with both the RIP and IF tests. These sera were from men attending a venereal disease department who appeared to match the men with NSU in sexual behaviour, and the possibility of a previous unsuspected genital infection must be considered. Rodin (1971) has shown that NSU may be completely asymptomatic; he found unequivocal evidence of NSU in 12.5 per cent. of symptom-free men by examining them after they had refrained from micturition overnight. Some of the positive serological results in our 'control' group could have been due to past asymptomatic chlamydial urethritis, although we do not know how long circulating antibodies persist after genital chlamydial infection. However, Chlamydia are ubiquitous organisms and, apart from genital infection, infection from other sources probably accounts for the majority of the positive results in the 'control' group, particularly with the RIP test which, as currently performed, is a groupreactive test and could indicate past contact with any chlamydial agent and not specifically those of the oculo-genital group.

Given a high background level of chlamydial antibodies, the use of the RIP and IF tests to evaluate men with Chlamydia-negative NSU presents difficulties. In this study we rarely found serological evidence of recent chlamydial infection in men with NSU unless the organisms themselves were isolated. Consequently, the role of Chlamydia in NSU, although established in perhaps one-half of patients, remains equivocal in the remainder.

The IF test is more specific than the RIP test, and with it we were able to examine sera against a range of chlamydial serotypes. The results indicate that the most common strains involved belong to subgroups $\mathrm{D}$ and $\mathrm{E}$; these strains are often isolated from patients with chlamydial infection of the genital tract and cross-reaction with LGV serotypes is common (Wang and Grayston, 1971).

These preliminary results show that both the RIP and the IF test may be of value in studying the role of Chlamydia in NSU, but more extensive surveys will be needed in the future, not only of patients with NSU but of control groups. No doubt the tests themselves could be improved in both sensitivity and specificity, and we are studying this at present.

\section{Summary}

Sera from 103 men with non-specific urethritis (NSU) were examined for chlamydial antibodies by the radioisotope precipitation (RIP) and microimmunofluorescence (IF) tests. Of 74 men with NSU from whom a chlamydial agent had been isolated, seventy (94 per cent.) gave positive results (titres $\geqq 1: 32$ ) with the RIP test. By the use of the IF test, 64 of the 74 men (86 per cent.) gave positive results (titres $\geqq 1: 8$ ) for IgG antibodies, and 21 ( 28 per cent.) positive results for IgM antibodies.

Sera from 29 men with NSU from whom a chlamydial agent had not been isolated were also examined. Of these, sixteen (55 per cent.) gave positive results with the RIP test, seven (24 per cent.) with the IF-IgG test, and one ( 3 per cent.) with the IF-IgM test. These figures did not differ significantly from those obtained from a control group of 37 men with no history or clinical evidence of NSU.

It is concluded from this preliminary study that both the RIP and the IF tests may be of value in demonstrating antibodies in the sera of patients with chlamydial genital infection. Serological evidence of recent chlamydial infection was rarely obtained from patients with NSU unless Chlamydia had been isolated on cell-culture.

We are grateful to Dr. C. S. Nicol for allowing us to study his patients. This project was supported by the Medical Research Council and by the Department of Health and Social Security.

\section{References}

Barwell, C. F., Dunlop, E. M. C., and Race, J. W. (1967) Amer. F. Ophthal., 63, 1527

Collier, L. H., SowA, J., and Sowa, S. (1972) f. Hyg. (Lond.), 70, 727

Dunlop, E. M. C., Vaughan-Jackson, J. D., Darougar, S., and JoNes, B. R. (1972) Brit. F. vener. Dis., 48, 425

Dwyer, R. St. C., Treharne, J. D., Jones, B. R., and HERRING, J. (1972) Ibid., 48, 452

Gerloff, R. K., and Watson, R. O. (1967) Amer. $\mathcal{F}$. Ophthal., 63, 1492

Gordon, F. B., Harper, I. A., Quan, A. L., Treharne, J. D., Dwyer, R. ST. C., and Garland, J. A. (1969) f. infect. Dis., 120, 451 
and Quan, A. L. (1965) Proc. Soc. exp. Biol. (N.Y.), 118, 354

Hanna, L., Jawetz, E., Nabli, B., Hoshiwara, I., OstLeR, B., and Dawson, C. (1972) f. Immunol., 108, 102

Oriel, J. D., Reeve, P., Powis, P., Miller, A., and Nicol, C. S. (1972) Brit. F. vener. Dis., 48, 429

Philip, R. N., Hill, D. A., Greaves, A. B., Gordon, F. B., QUAN, A. L., GerLOFF, R. K., and ThOMAS, L. A. (1971) Ibid., 47, 114

Richmond, S. J., Hilton, A. L., and Clarke, S. K. R. (1972) Ibid., 48, 437

RodIN, P. (1971) Ibid., 47, 452

WANG, S. P. (1971) In 'Trachoma and Related Disorders', ed. R. L. Nichols, p. 273. Excerpta Medica, Amsterdam (Int. Congress Ser., No 223)

- and Grayston, J. T. (1971) Idem, p. 305

\section{Etudes sérologiques sur le rôle des Chlamydia dans l'étiologie de l'urétrite non spécifique}

\section{SOMMAIRE}

On rechercha les anticorps chlamydiaux dans le sérum de 103 hommes atteints d'urétrite non spécifique (UNS) par les épreuves de marquage radio-isotopique (RIP) et par micro-immunofluorescence (IF). Chez 74 hommes atteints de UNS chez lesquels un agent chlamydial avait été isolé, 70 (94 pour cent) donnèrent des résultats positif (titre $\geqslant 1: 32$ ) à l'épreuve RIP. Avec l'épreuve IF, 64 de ces 74 hommes (86 pour cent) donnèrent des résultats positifs (titre $\geqslant 1: 8$ ) pour les anticorps IgG et 21 (28 pour cent) pour les anticorps IgM.

Les sérums de 29 hommes atteints d'UNS chez lesquels on n'avait pas isolé d'agent chlamydial furent aussi examinés. Parmi ceux-ci, 16 (55 pour cent) donnèrent des résultats positifs pour l'épreuve RIP, 7 (24 pour cent) pour l'épreuve IF-IgG et 1 ( 3 pour cent) pour l'épreuve IF-IgM. Ces chiffres ne furent pas significativement différents de ceux que l'on obtint dans un groupe témoin de 37 hommes n'ayant ni historie ni évidence clinique d'UNS.

On conclut de cette étude préliminaire que les deux tests RIP et IF peuvent avoir de la valeur pour mettre en évidence des anticorps dans le sérum de malades atteints d'infection génitale à Chlamydia. La preuve sérologique d'une infection chlamydiale récente fut rarement obtenue pour les malades atteints d'UNS si Chlamydia n'avait pas été isolé en culture cellulaire. 